\title{
DATOWANIE RADIOWĘGLWE GROBÓW KOMOROWYCH Z WCZESNOŚREDNIOWIECZNEGO CMENTARZYSKA W SOWINKACH (STAN. 23A) W WIELKOPOLSCE
}

\author{
RADIOCARBON DATING OF CHAMBER GRAVES FROM \\ THE EARLY MEDIEVAL CEMETERY AT SOWINKI (SITE 23A) \\ IN WIELKOPOLSKA
}

\author{
Andrzej Krzyszowski \\ Muzeum Archeologiczne w Poznaniu \\ ul. Wodna 27, 61-781 Poznań, Poland \\ andrzej.krzyszowski@muzarp.poznan.pl \\ Dariusz Btaszczyk \\ Instytut Archeologii, Uniwersytet Warszawski \\ ul. Krakowskie Przedmieście 26/28, 00-927 Warszawa, Poland \\ d.blaszczyk@uw.edu.pl
}

ABSTRACT. This paper presents and discusses the results of ${ }^{14} \mathrm{C}$ dating of two chamber graves (no. 148 and 151) from the early medieval cemetery at Sowinki, site 23A (Wielkopolska).

KEY WORDS: burial archaeology, early medieval cemeteries, chamber graves, radiocarbon dating

\section{WPROWADZENIE}

Stanowisko archeologiczne w Sowinkach nr 23A (gm. Mosina, pow. poznański, woj. wielkopolskie) znajduje się około $35 \mathrm{~km}$ na południowy wschód od Poznania. Stanowisko jest usytuowane na rozległym, piaszczystym cyplu znajdującym się nad 
krawędzią terasy nadzalewowej doliny rzeki Warty (ryc. 1). Zostało ono przebadane wykopaliskowo w latach 1989-1991 w związku z projektowaną w tym miejscu budową stacji uzdatniania wody dla miasta Poznania. Badaniami kierował Andrzej Krzyszowski z ramienia ówczesnej Pracowni Naukowo-Badawczej PKZ w Poznaniu Sp. z o.o. Stanowisko w Sowinkach miało charakter wielokulturowy, bowiem odkryto, oprócz rozległego cmentarzyska z wczesnego średniowiecza, także pozostałości osadnictwa z okresu późnego mezolitu, neolitu, kultury łużyckiej, kultury pomorskiej, kultury przeworskiej i z późnego średniowiecza (Krzyszowski 1992, 1995, 1997, 2014).

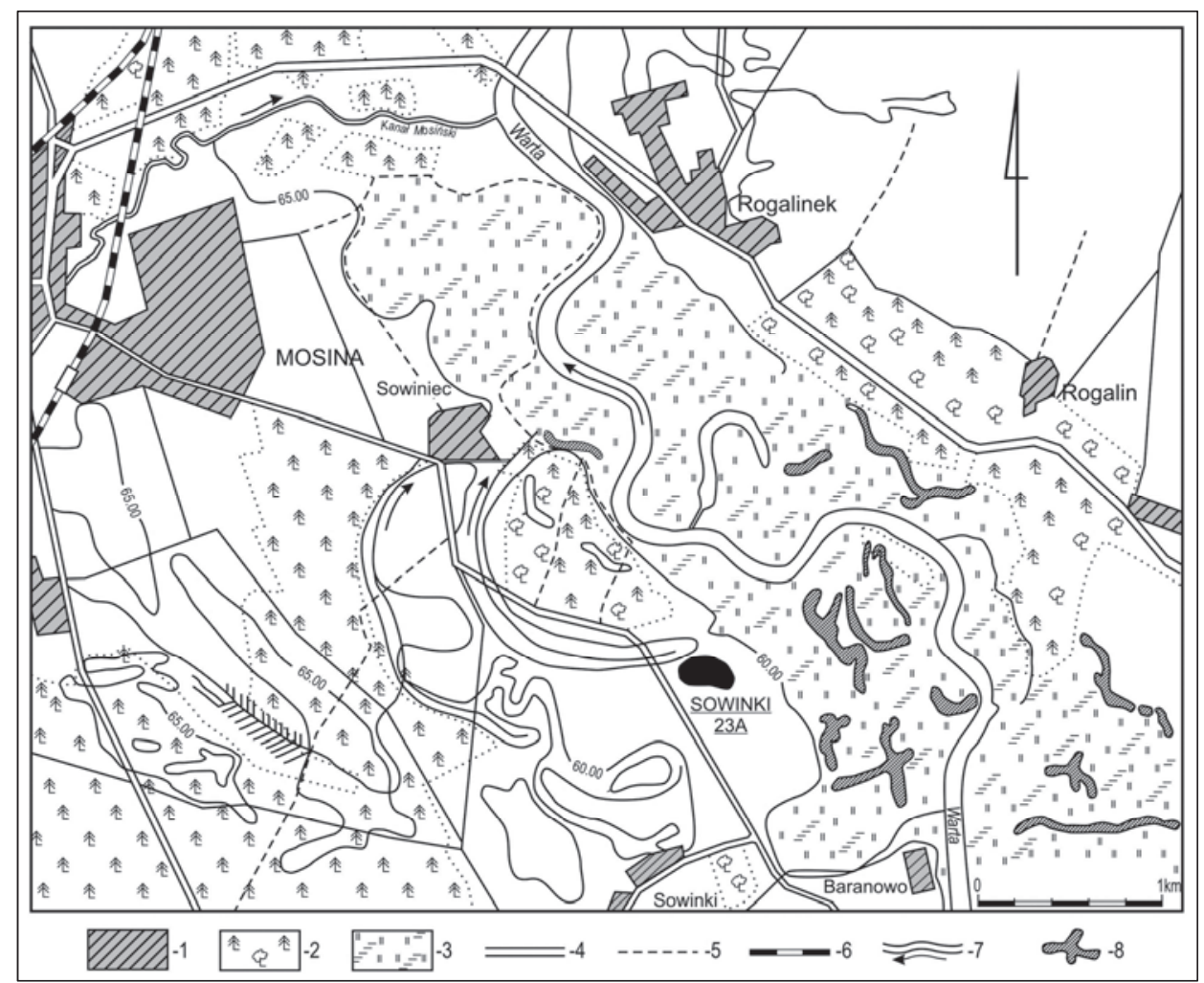

Ryc. 1. Sowinki, gm. Mosina, stan. 23A. Położenie stanowiska na tle fizjograficznym: 1 - współczesne miejscowości; 2 - obszary leśne; 3 - tereny podmokłe; 4 - współczesne drogi; 5 - drogi polne; 6 - tory kolejowe; 7 - cieki wodne; 8 - starorzecza (rys. W. Kudra i B. Bednarczyk, oprac. komp. B. Bednarczyk)

Fig. 1. Sowinki, Mosina Commune, site 23A. Location of the site in the landscape: 1 - contemporary towns and villages; 2 - forests; 3 - wetlands; 4 - contemporary roads; 5 - field roads; 6 - railway track; 7 - watercourses; 8 - oxbow lakes (drawn by W. Kudra and B. Bednarczyk, digitalised by B. Bednarczyk) 


\section{CHARAKTER CMENTARZYSKA I GROBÓW KOMOROWYCH}

W czasie prac archeologicznych prowadzonych na stanowisku Sowinki 23A odkryto całkowicie szkieletowe cmentarzysko $\mathrm{z}$ okresu wczesnego średniowiecza (ryc. 2). W jego ramach wyeksplorowano 150 grobów zawierających 158 pochówków. Osiem z odkopanych grobów nie zawierało szkieletów, które najprawdopodobniej uległy całkowitemu rozkładowi. Stan zachowania kości w pozostałych grobach również był zły lub bardzo zły. Określenia płci i wieku, opracowania antropologicznego oraz demograficznego odkrytych szkieletów dokonał Jerzy Kozak z Instytutu Antropologii UAM w Poznaniu (Kozak 1996).

Większość zmarłych na cmentarzysku w Sowinkach pochowano w pojedynczych grobach, natomiast w kilku przypadkach do tej samej jamy grobowej złożono

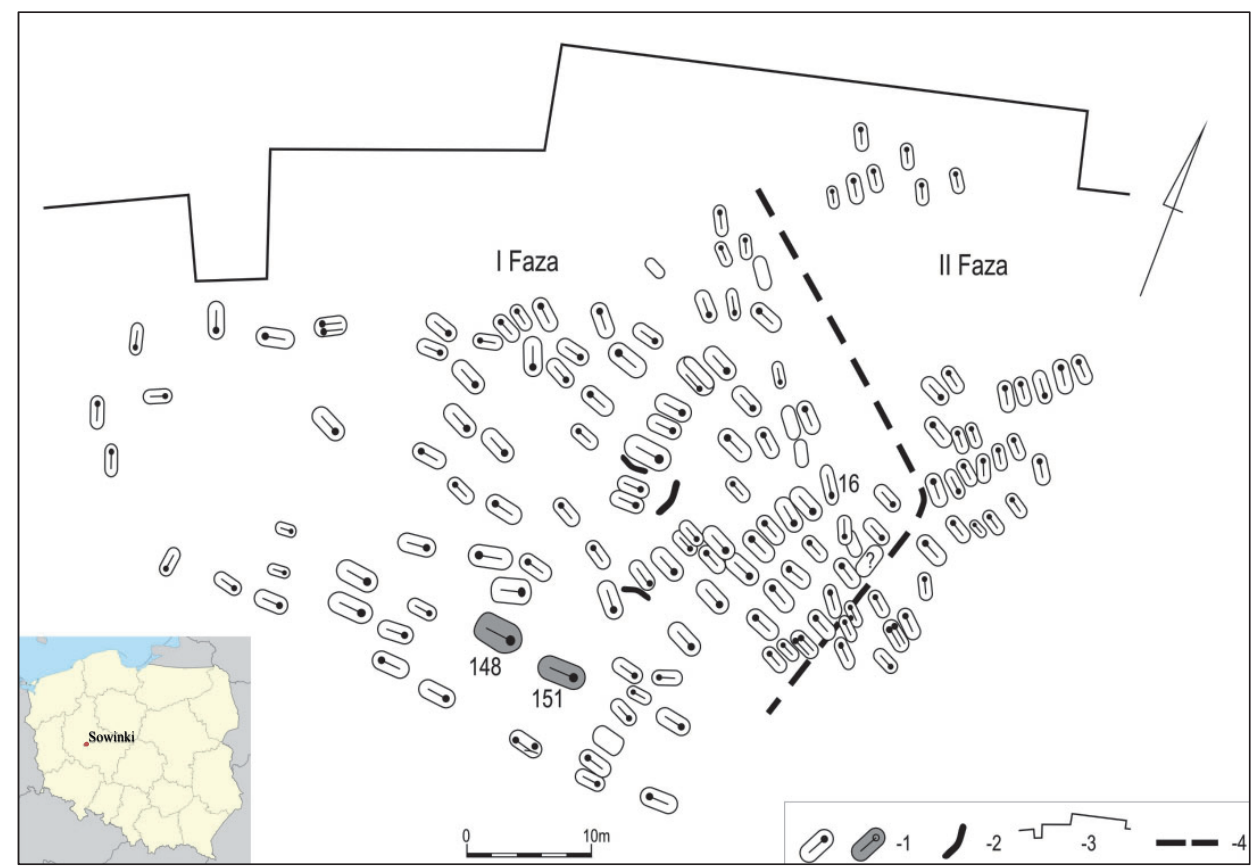

Ryc. 2. Sowinki, gm. Mosina, stan. 23A. Plan cmentarzyska z okresu wczesnego średniowiecza z zaznaczeniem orientacji pochówków (kolorem szarym i numerem oznaczono groby komorowe nr 148 i 151): 1 - zarysy grobów z zaznaczeniem orientacji pochówka; 2 - nieokreślone obiekty z okresu wczesnego średniowiecza; 3 - północna granica wykopu; 4 - prawdopodobna granica między starszą i młodszą częścią cmentarzyska (oprac. komp. B. Bednarczyk)

Fig. 2. Sowinki, Mosina Commune, site 23A. The plan of the early medieval cemetery showing the orientation of burials (chamber graves no. 148 and 151 are marked in grey and numbered): 1 - outline of the grave with marked orientation of the interment; 2 - indeterminate early medieval features; 3 - northern boundary of the trench; 4 - probable boundary between the older and the younger part of the cemetery (digitalised by B. Bednarczyk) 
dwóch zmarłych. Jamy grobowe miały przeważnie kształt prostokątny z zaokrąglonymi narożnikami i w większości były orientowane na linii wschód-zachód, nieliczne natomiast miały orientację północ-południe (np. groby nr 159, 404, 409, 414). Ich rozmiary wynosiły od 2,1 do 3,8 m długości, od 0,6 do 2,7 m szerokości i od 0,15 do $1,15 \mathrm{~m}$ głębokości. Wyposażenie grobowe stwierdzono w przypadku 82 pochówków. Na podstawie materiału zabytkowego występującego w grobach określono, że cmentarzysko w Sowinkach było użytkowane od 2. połowy X do 1. połowy XII w. Datowanie konwencjonalne potwierdzono również datowaniem wieku rozpadu węgla ${ }^{14} \mathrm{C}$ próbek z kilku grobów w Poznańskim Laboratorium Radiowęglowym $^{1}$. Z próbek kości i węgli drzewnych uzyskano daty, które pozwalają wydzielić przestrzennie dwie fazy chronologiczne cmentarzyska (ryc. 2): starszą chronologicznie zajmującą jego centralno-zachodnią partię i datowaną na okres między $\mathrm{X} / \mathrm{XI}$ a 1. poł. XI w. W strefie tej zanotowano wyłącznie groby uformowane w kilka mniej więcej równoległych ciągów, bez charakterystycznego układu rzędowego, dominującego z kolei w „młodszej” (faza II) chronologicznie partii południowo-wschodniej, datowanej na okres od 2. poł. XI w do 1. poł. XII w.

Do tej pory jedynie cząstkowo udało się ustalić kontekst osadniczy cmentarzyska w Sowinkach, natomiast nie udało się zidentyfikować osady (osad) lub grodu, których mieszkańcy mogli być na nim chowani (temat jest aktualnie w przygotowaniu; zob. Krzyszowski 1992, s. 100, p. 16).

Kilka odkrytych grobów ze względu na swoją formę i rodzaj wyposażenia odróżniało się od pozostałych obiektów odkrytych na cmentarzysku. Można dostrzec w kilku przypadkach (obiekty $\mathrm{nr} 70,148,151$ ), że były to niewątpliwie pochówki osób zajmujących znaczną pozycję w strukturze ówczesnej społeczności, a wręcz można stwierdzić z dużym prawdopodobieństwem, że byli to najpewniej przedstawiciele ówczesnej elity społecznej: kupiec odkryty w grobie nr 70, zbrojny jeździec złożony do grobu nr 151 oraz bodajże jedna z najważniejszych osób pochowanych na tym cmentarzu, którą złożono $\mathrm{w}$ grobie $\mathrm{nr} 148$, to prawdopodobnie również osoba o czynnościach natury wojskowej (określenie wg Jerzego Gąssowskigo 1952

\footnotetext{
${ }^{1}$ Analizę wykonał zespół pod kierunkiem prof. dr. hab. Tomasza Goslara z UAM w Poznaniu. Uzyskano następujące przedziały kalibrowanego wieku kalendarzowego: dla obiektu 61 (Poz-43126,

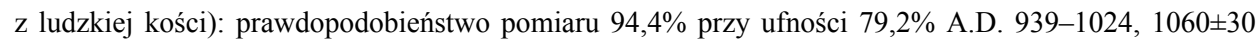
BP; dla obiektu 70 (Poz-43127, z fragmentu drewna ze skrzyneczki zawierającej brązową składaną wagę): prawdopodobieństwo pomiaru $95,4 \%$ przy ufności $92,1 \%$ A.D. $805-978,1145 \pm 30$ BP; dla obiektu 367 (Poz-43128, z ludzkiej kości): prawdopodobieństwo pomiaru 95,4\% przy ufności 52,5\% A.D. $1116-1211,900 \pm 30$ BP (tab. 1). Analizy ${ }^{14} \mathrm{C}$ zrealizowano ze środków MNiSW, grantu kierowanego przez dr Danutę Michalską-Nawrocką z Instytutu Geologii Uniwersytetu im. A. Mickiewicza w Poznaniu, w tym z jej grantu własnego (nr N N307 059437) w ramach prowadzonego przez nią projektu pn. „Modelowanie procesów zachodzących w próbkach materiałów przeznaczonych do datowania metodą radiowęglową" oraz grantu Iuventus Plus IP2010 027870; za możliwość analizy próbek z Sowinek serdecznie dziękuję Pani dr Danucie Michalskiej-Nawrockiej.
} 
«1950», s. 165). Tę ostatnią osobę można najprawdopodobniej utożsamiać z książęcym notablem, który w zamian za swoją służbę na rzecz dworu książęcego (na Ostrowie Tumskim w Poznaniu) i jego z nadania „otrzymał” osiedle razem z jego ieszkańcami, przy którym u schyłku X w. założono nekropolę.

Te dwa ostatnie obiekty (nr 148 i 151) charakteryzowały się ponadto obszernymi jamami grobowymi, śladami drewnianych konstrukcji grobowych oraz bogatym wyposażeniem, co pozwoliło zidentyfikować je jako tzw. groby komorowe. Podobne groby odkryto m.in. na cmentarzyskach w Kałdusie, Pniu, Bodzi, Dziekanowicach i Ciepłem (omówienie zagadnienia wczesnośredniowiecznych grobów komorowych z ziem polskich, zob. m.in. w: Błaszczyk, Stępniewska red. 2016; Janowski 2011a, 2011b, 2015; Müller-Wille 2015; Sikora 2013; Wrzesiński 2010; tam dalsza literatura). Oba groby nr 148 i 151 były zlokalizowane w południowej części
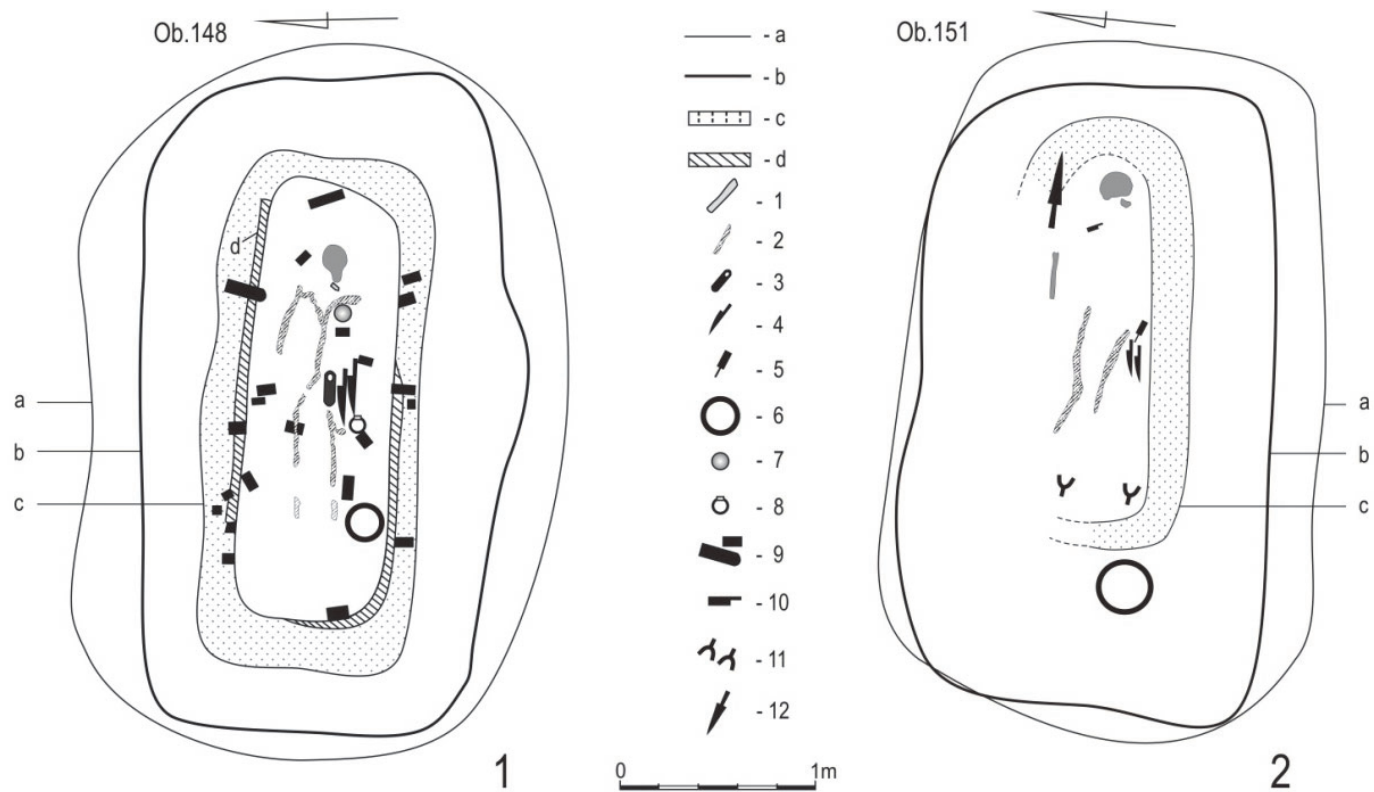

Ryc. 3. Sowinki, gm. Mosina, stan. 23A. Plany płaskie grobów komorowych nr 148(1) i 151(2) z zaznaczeniem miejsca zalegania przedmiotów towarzyszących. Legenda: a - zarys jamy grobowej na poziomie stropu, b - zarys jamy grobowej na poziomie szkieletu, c - zarys trumny, d - negatywy drewna trumny; 1 - zachowane kości, 2 - negatywy po kościach, 3 - kamień probierczy, 4 - nóż żelazny, 5 - żelazne szydło, 6 - wiaderko klepkowe, 7 - srebrna moneta, 8 - srebrny pierścień, 9 - żelazne okucie trumny, 10 - brzytwa żelazna, 11 - ostrogi żelazne, 12 - żelazny grot włóczni (rys. i oprac. komp. B. Bednarczyk)

Fig. 3. Sowinki, Mosina Commune, site 23A. Plans of chamber graves no. 148(1) and 151 (2), showing the position of deposited accompanying artefacts. Legend: a - an outline of the grave pit on the top level. B - an outline of the grave pit on the bottom level, $\mathrm{c}$ - an outline of a coffin; $\mathrm{d}$ - traces of a wooden coffin; 1 - preserved bones, 2 - traces of decayed bones, 3 - touchstone, 4 - an iron knife, 5 - an iron awl, 6 - a stave bucket, 7 - a silver coin, 8 - a silver finger ring, 9 - an iron coffin ferrule, 10 - an iron razor, 11 - an iron spurs, 12 - an iron spearhead (drawn and digitalised by B. Bednarczyk) 

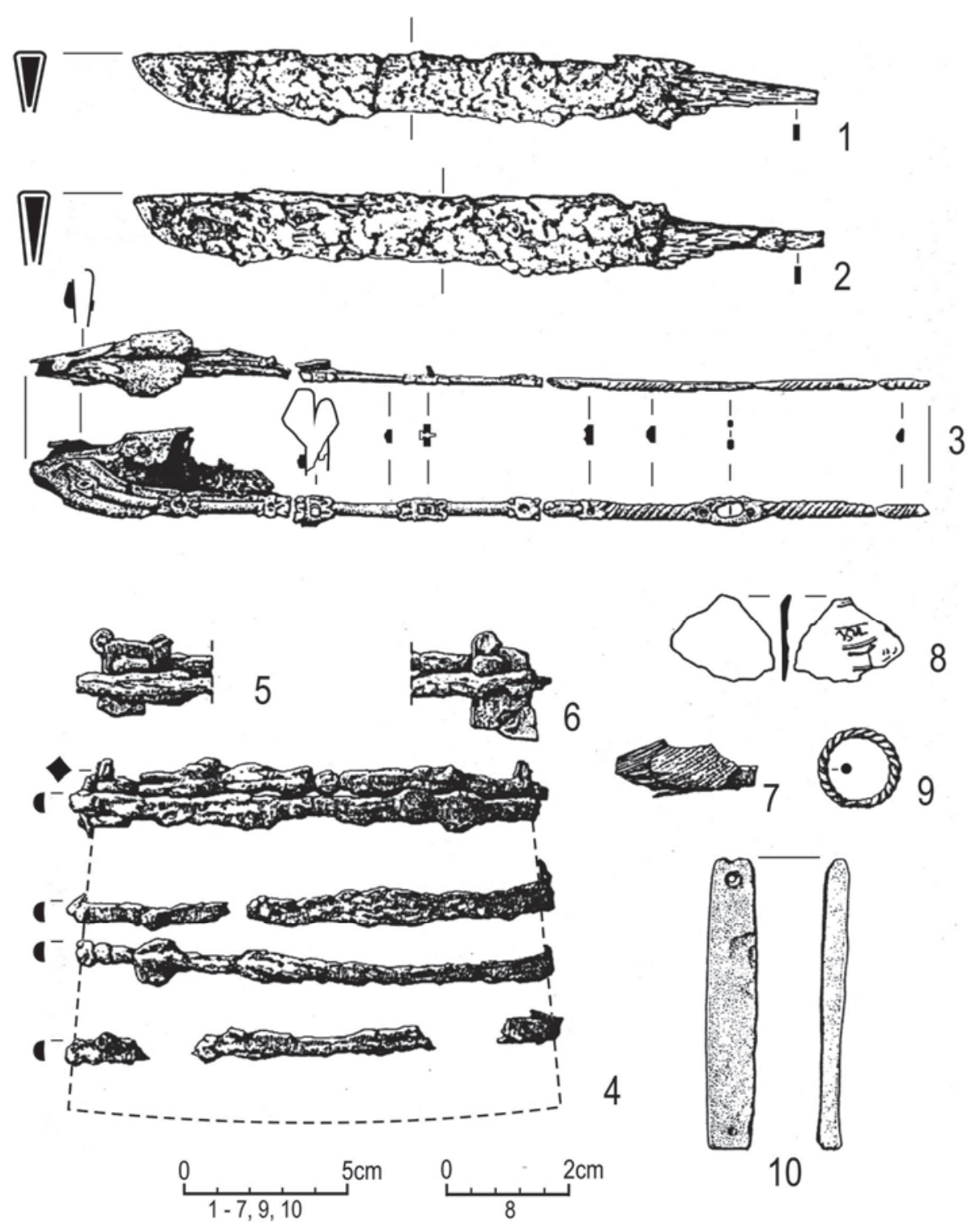

Ryc. 4. Sowinki, gm. Mosina, stan. 23A. Inwentarz grobu komorowego nr 148: 1-2 - noże żelazne w skórzanych pochewkach; 3 - brązowe i pozłacane okucie pochewki dwóch noży żelaznych; 4 -żelazne obręcza wiaderka klepkowego, in situ, ze zbliżeniem na uszka (5-6) i fragment tkaniny przytwierdzony do obręczy (7); 8 - srebrny dirhem arabski; 9 - srebrny pierścień; 10 - kamień probierczy z fyllitu (rys. W. Kudra, oprac. komp. B. Bednarczyk)

Fig. 4. Sowinki, Mosina Commune, site 23A. Funerary equipment of the chamber grave no. 148 (1-2 - iron knives in leather sheaths; 3 - bronze and gold-plated fitting of a sheath of two iron knives; 4 - an iron ring of a stave bucket, in situ, with a close-up on the handles (5-6) and a piece of fabric attached to the ring (7); 8 - a silver Arabic dirham; 9 - a silver finger ring; 10 - a touchstone made of phyllite (drawn by W. Kudra, digitalised by B. Bednarczyk) 
cmentarza, na jego skraju, w układzie liniowym, jeden za drugim. W ich pobliżu znajdowały się kolejne dwa groby o również bardzo bogatym wyposażeniu (groby $\mathrm{nr} 69$ i 70), które jednak nie miały charakteru grobów komorowych (Krzyszowski 1997). Zarówno grób nr 148, jak i grób nr 151 odsłonięto w 1989 r. w wykopie I/1989. Są to jedne z pierwszych wczesnośredniowiecznych grobów komorowych odkrytych na ziemiach polskich. Grób nr 148 (ryc. 3:1) był pochówkiem osoby o nieustalonej płci $\mathrm{w}$ wieku juvenis, natomiast biorąc pod uwagę towarzyszące zmarłemu wyposażenie, mógł to być mężczyzna. Jama grobowa była usytuowana na linii wschód-zachód, miała kształt nieregularnego prostokąta z zaokrąglonymi narożnikami. Jej wypełnisko stanowił szarobrunatny, przemieszany piasek. Wymiary jamy grobowej wynosiły 3,78 $\mathrm{m}(\mathrm{d}$.) $\times 2,60 \mathrm{~m}$ (szer.), przy głębokości - 1,19 m. W grobie odkryto pozostałości trumny $\mathrm{w}$ postaci śladów drewna oraz 8 żelaznych okuć (4 pary) i 16 gwoździ, które służyły do przybicia okuć do trumny. Zmarły był ułożony w pozycji wyprostowanej na plecach z rękoma wyciągniętymi wzdłuż ciała i wyprostowanymi nogami. Głową był zwrócony w kierunku wschodnim, a twarzą skierowany na zachód. Przy zmarłym znaleziono dwa żelazne noże we wspólnej skórzanej pochewce ozdobionej trzewikiem z okuciami z brązu platerowanymi złotą blaszką i stylizowanym przedstawieniem żmii lub smoka, kamień probierczy z fyllitu (zob.

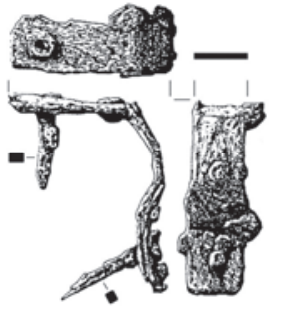

1

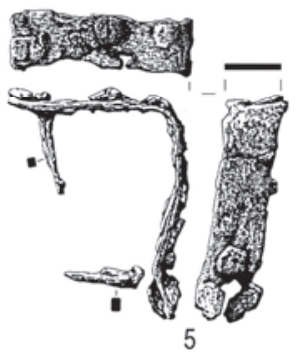

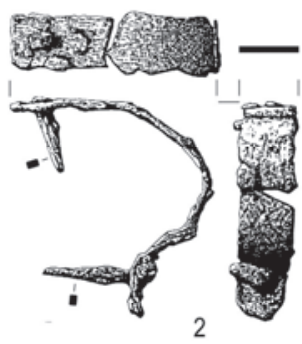

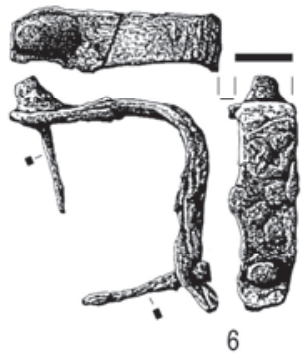

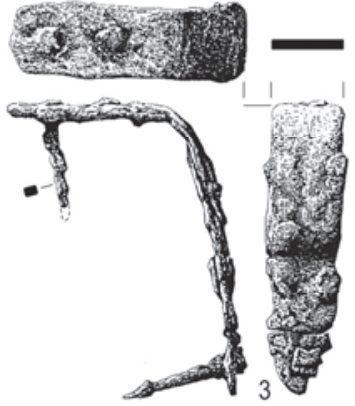

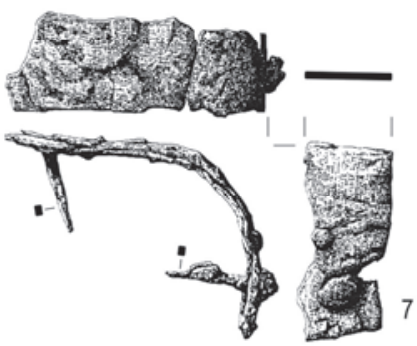

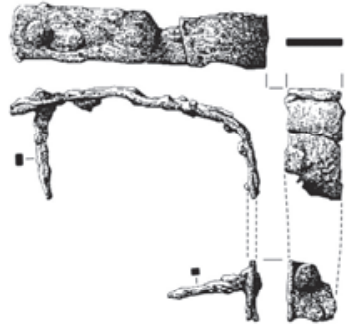

4
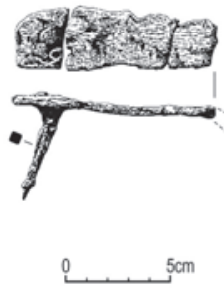

Ryc. 5. Sowinki, gm. Mosina, stan. 23A. Żelazne okucia trumny z grobu komorowego nr 148 (rys. W. Kudra, oprac. komp. B. Bednarczyk)

Fig. 5. Sowinki, Mosina Commune, site 23A. The iron coffin ferrules from the chamber grave no. 148 (drawn by W. Kudra, digitalised by B. Bednarczyk) 
Ježek, Krzyszowski, Zavřel 2013), wiaderko klepkowe, duży srebrny pierścień wykonany $z$ trzech splecionych ze sobą drutów i 1/4 srebrnego dirhema arabskiego. Łącznie odkryto w tym grobie 30 przedmiotów (ryc. 4) i obiekt ten należy do najważniejszych obiektów sepulkralnych odkrytych na tym cmentarzysku (Krzyszowski 1992, 1995, 1997, 2014).

Jama drugiego grobu komorowego nr 151 (ryc. 3:2) również była usytuowana na linii wschód-zachód. Miała kształt nieregularnego prostokąta z zaokrąglonymi narożnikami i mierzyła 3,64 m (dł.) × 2,30 m (szer.), przy głębokości 1,08-1,11 m. Jej wypełnisko stanowił szarobrunatny, przemieszany piasek. W grobie tym, podobnie jak w grobie nr 148, odkryto szczątki osoby o nieustalonej płci w wieku juvenis. Biorąc pod uwagę wyposażenie grobowe zmarłego, prawdopodobnie był to również mężczyzna. W grobie zachowały się pozostałości trumny w postaci śladów drewna. Zmarły był ułożony w pozycji wyprostowanej na wznak, z rękoma prawdopodobnie wyciągniętymi wzdłuż ciała i wyprostowanymi nogami. Jego głowa była skierowana na wschód, a twarz na zachód. Przy zmarłym znaleziono (ryc. 6): dwa żelazne noże umieszczone, podobnie jak w grobie nr 148, w jednej, ale podwójnej skórzanej pochwie skutej pojedynczym brązowym okuciem ozdobionym stylizowanym przedstawieniem żmii lub smoka, żelazny grot włóczni, dwie żelazne ostrogi razem z pojedynczą żelazną sprzączką do ostróg, wiaderko obite w górnej części żelazną blachą, platerowaną srebrem i zdobioną puncowaniem, fragment żelaznego przedmiotu, który pełnił zapewne rolę szydła oraz fragment innego przedmiotu żelaznego, który mógł być brzytwą.

W zakresie chronologii konwencjonalnej najlepszym elementem datującym w grobie nr 148 jest niewątpliwie fragment dirhema arabskiego, którego czas wybicia przypada na okres panowania dynastii Sammanidów lub Buwajhidów, tj. na lata 950-976, zaś przypuszczalny czas jego złożenia w tym grobie Anna Kmietowicz (1994) określiła na czwartą ćwierć X w. Z kolei w grobie nr 151 zabytkami pozwalającymi na jego datowanie są dwie ostrogi i grot włóczni. Obie ostrogi są żelazne i reprezentują morfologicznie typ I ostróg z bodźcem nierozczłonkowanym zakończonym stożkowato (kolcowym) wg typologii Zofii Hilczerówny (1956, s. 22 i n., tabl. II). Mają one wydłużone kabłąki w kształcie litery U, zakończone płytkowatymi czworokątnymi zaczepami, z których jeden ma dwa żelazne nity, zaś drugi jeden otwór do nitu. Różnią się prostymi bodźcami: u jednej z ostróg bodziec jest krótszy (mierzy $5 \mathrm{~cm}$ ) i leży w tej samej płaszczyźnie co kabłąk - stanowiąc odmianę 1 . typu I, zaś u drugiego okazu bodziec jest nieco dłuższy (ma $6 \mathrm{~cm}$ długości) i jest nieznacznie uniesiony ku górze - w związku z tym można tę ostatnią ostrogę kwalifikować już do odmiany 2. typu I. Długość obu ostróg jest jednak taka sama i wynosi $17 \mathrm{~cm}$, z kolei rozpiętość ramion osiąga $\mathrm{w}$ obu przypadkach po $10 \mathrm{~cm}$. Przekroje ramion i bodźców są mocno zróżnicowane. Na jednej $\mathrm{z}$ ostróg zaobserwowano na kabłąku (u nasady z bodźcem) śladowo zachowany ornament $\mathrm{w}$ postaci rytych rowków, ujawniony dopiero po konserwacji. Najbliższe analogie do zdobnictwa obu 

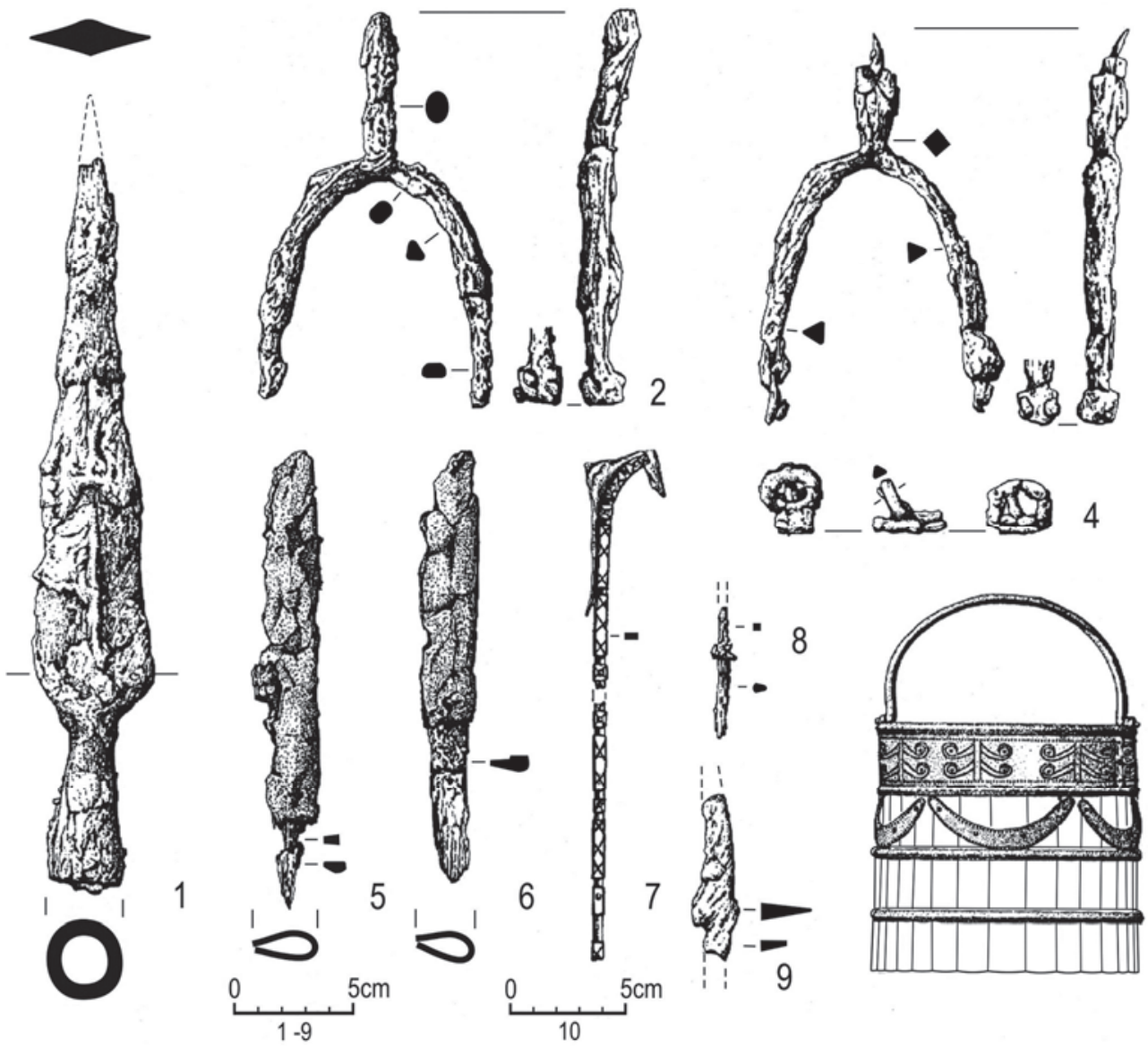

Ryc. 6. Sowinki, gm. Mosina, stan. 23A. Inwentarz grobu komorowego nr 151: 1 - żelazny grot włóczni; 2-3 - żelazne ostrogi; 4 - żelazna sprzączka od ostrogi; 5-6 - żelazne noże w skórzanych pochewkach; 7 - brązowe okucie pochewki dwóch noży żelaznych; 8 - fragment żelaznego szydła; 9 - fragment żelaznej brzytwy; 10 - rekonstrukcja wiaderka klepkowego (rys. W. Kudra, oprac. komp.

$$
\text { B. Bednarczyk) }
$$

Fig. 6. Sowinki, Mosina Commune, site 23A. Funerary equipment of the chamber grave no. 151: 1 - an iron spearhead; 2-3 - iron spurs; 4 - an iron clasp for a spur, 5-6 - iron knives in leather sheaths; 7 - a bronze fitting of a sheath of two iron knives; 8 - a fragment of an iron awl; 9 - a fragment of an iron razor; $10-$ a reconstruction of a stave bucket (drawn by W. Kudra, digitalised by B. Bednarczyk)

ostróg z Sowinek znajdujemy na cmentarzysku w Luboniu (Hilczerówna 1956, tabl. II) i Lutomiersku (Nadolski, Abramowicz, Poklewski 1959, tabl. XLIa, c-d). Natomiast dobrą analogię do dwóch odmian tego samego typu ostróg, typu I, z Sowinek stanowi para ostróg również tego typu odkryta w jednym z grobów komorowych (III) na cmentarzysku w Süderbrarup w Schlezwiku-Holsztynie (Aner 1952, Abb. 3,1.4). 
Ostrogi typu I z Sowinek można datować na 2. połowę X i na 1. połowę XI w. (Hilczerówna 1956, s. 26-31). Podobną chronologię dla tego typu ostróg proponuje Andrzej Nadolski (1954, s. 82-83). Okazy z Sowinek reprezentują wg typologii tego badacza typ II (tzw. wikiński), a w jej ramach formę starszą chronologicznie, z kolcem niewyodrębnionym. Chronologia ta została ostatnio potwierdzona również datą ${ }^{14} \mathrm{C}$ uzyskaną z kości zmarłego pochowanego w grobie $\mathrm{nr} 151$, gdzie odkryto oba omawiane przedmioty (o czym poniżej). Michał Kara (1991, s. 105), analizując wczesnośredniowieczne groby z uzbrojeniem z terenu Wielkopolski, stwierdził, że ostrogi typu znalezionego w Sowinkach (I:1-2) - pojawiły się w Europie Środkowej w końcu IX w. i pozostawały w użyciu do około połowy XI w., zaś genetycznie są one kontynuacją okazów płytkowych z terenów późnej dynastii Karolingów w państwie Franków i z państwa wielkomorawskiego. Badacz ten przyjmuje, że na terenie Wielkopolski i Kujaw ostrogi tego typu były w większości ,importami” z terenu Skandynawii lub Europy Środkowo-Zachodniej (Niemcy, Czechy, Morawy). Podobny pogląd wyraża Kazimierz Wachowski (1992, s. 36-37; w typologii tegoż autora okazy z Sowinek reprezentowałyby typ V M z poziomo ułożonymi nitami na płytce), który uznaje je za niewątpliwie wytwór późnokaroliński, które sporadycznie występują też na Morawach i Słowacji, ale też na Śląsku i w Skandynawii. Chronologię tego typu ostróg Kazimierz Wachowski (1988, s. 60-62, ryc. 2) odnosi do IX w.

Z kolei grot włóczni z tego samego grobu nr 151 zakwalifikowano do typu G wg typologii Jana Petersena (1919, s. 29, ryc. 17-18) i do typu III wg Andrzeja Nadolskiego (1954, s. 54, tabl. 21:1-4). Posiada on następujące wymiary: całkowita długość wraz z krótką i kolistą tulejką - $32 \mathrm{~cm}$, maksymalna szerokość liścia w kształcie deltoidu, o przekroju płasko-soczewkowatym - 4,5 cm, maksymalna grubość liścia - 1,3 cm, średnica wylotu tulei - 2,6 (na zewnątrz) i 2,0 cm (wewnątrz), grubość tulei - $3 \mathrm{~mm}$. Zbliżone okazy grotów tego typu znajdujemy na wielu wczesnośredniowiecznych stanowiskach z Wielkopolski, w tym również na stanowiskach grodowo-osadowych, m.in. w Iwnie k/Środy Wlkp. (Rajewski 1938, tabl. VII:2-3), w Łubówku (Rajewski 1938, s. 35, tabl. VII:4-6), w Młodzikowie (Leciejewicz, Łosiński 1960, s, 130, ryc. 46:1), w Daniszewie (Sawicki 2008, ryc. 5:2), na Ostrowie Lednickim (Tokarski 2000, tabl. VI:1,9), na ziemi łódzkiej i radomskiej: w Końskich (Gąssowski 1952 (1950), tabl. X:1; XI:6; XIV:6), w Lutomiersku (Nadolski, Abramowicz, Poklewski 1959, XXXIX:d; Grygiel 2014, ryc. 11:2; 26:3-6), w Lubieniu (Kurasiński, Skóra 2012a, tabl. LXIV:1; LXXVIII:2) czy Radomiu (Kurasinski, Skóra 2012b, ryc. 1:1, 3) oraz w Małopolsce (Morawski, Zaitz 1977, tabl. V:3), na Opolszczyźnie (Wachowski 1984, ryc. 3:b), w Meklemburgii (Kempke 1991, ryc. 4:3; Unwerzagt, Schuldt 1963, tabl. 48:a) czy na Pomorzu Gdańskim (Ratajczyk 2013, fig. 11:b). Groty w typie, jaki został znaleziony w grobie $151 \mathrm{w}$ Sowinkach, są powszechnie spotykane na terenach skandynawskich i bałtyjskich, gdzie niektóre z nich mają często efektownie zdobioną tulejkę (np. Petersen 1919, s. 17-18, 25). 
Okazy tego typu są datowane na 2. połowę X w. (pod sam koniec tego wieku) oraz początki XI w. i należą na ziemiach polskich do rzadkich znalezisk (Petersen 1919, s. 29; Nadolski 1954, s. 54; Żak 1967, s. 296-297). Ich powstanie tłumaczy się kontaktami terenów skandynawskich z obszarami Nadrenii (Żak 1967, s. 295; 1968, s. 296). W Skandynawii tego rodzaju groty były używane przez ciężkozbrojnych i lekkozbrojnych jeźdźców (Leciejewicz 1954, s. 154, 158; Żak 1967, s. 295). Wyżej wymienione przedmioty z obu grobów, wespół z wiaderkami klepkowymi (w tym bogato zdobionym okazem znalezionym w grobie nr 151), jak również sposób ich ułożenia przy zmarłych i, jak w przypadku grotu włóczni w obrębie tzw. strony władzodajnej (chodzi o prawą stronę), świadczą, że w obu omawianych obiektach złożono niewątpliwie przedstawicieli miejscowej elity społecznej, zaś w przypadku pochówku z grobu nr 151, drugim z okazałych grobów typu komorowego na tym cmentarzysku, zmarłego można najprawdopodobniej identyfikować z wojem służącym w jeździe (Krzyszowski 1992, 1995, 2014).

\section{DATOWANIE ${ }^{14} \mathrm{C}$}

Dla oznaczenia wieku radiowęglowego pochówków w grobach nr 148 i 151 pobrano próbki z fragmentów kości pochowanych tam osób. Datowanie ${ }^{14} \mathrm{C}$ przeprowadzono w Poznańskim Laboratorium Radiowęglowym kierowanym przez profesora Tomasza Goslara ${ }^{2}$. Badanie wykonano za pomocą techniki akceleratorowej (AMS - Accelerator Mass Spectometry) przy pomocy akceleratorowego spektrometru masowego typu 1.5 SDH-Pelletron Model „Compact Carbon AMS” nr ser. 012. Technika ta polega na zliczaniu poszczególnych atomów węgla i pozwala na uzyskanie dużej precyzji pomiaru, przy konieczności pobrania do badań tylko niewielkiej próbki (Walanus, Goslar 2009). Kalibracji uzyskanych dat radiowęglowych dokonano w programie OxCal 4.2 względem krzywej IntCal 13 (https://c14.arch.ox.ac.uk).

Dla grobu nr 148 uzyskano datę $1100 \pm 30$ BP (Poz-72015), (Goslar 2015). Kalibracja tego wieku daje wyniki: prawdopodobieństwo $27.8 \%$ dla okresu 898AD925AD; prawdopodobieństwo 40,4\% dla okresu 944AD-985AD i prawdopodobieństwo $95,4 \%$ dla okresu $887-1013$ AD (tab. 1, ryc. 7).

Natomiast dla grobu nr 151 otrzymano datę $1090 \pm 30$ BP (Poz-64262), (Goslar 2014). Kalibracja tego wieku daje wyniki: prawdopodobieństwo $24,2 \%$ dla okresu 899AD-924AD, prawdopodobieństwo 44,0\% dla okresu 945AD-990AD, prawdopodobieństwo 95,4\% dla okresu 892-1014 AD (tab. 1, ryc. 8).

\footnotetext{
${ }^{2}$ Badania ${ }^{14} \mathrm{C}$ zostały sfinansowane ze środków Narodowego Centrum Nauki przyznanych p. Dariuszowi Błaszczykowi w ramach finansowania stażu po uzyskaniu stopnia naukowego doktora na podstawie decyzji numer DEC-2013/08/S/HS3/00178 (projekt „Swoi czy obcy? Pochówki w grobach komorowych na ziemiach polskich w okresie wczesnego średniowiecza").
} 


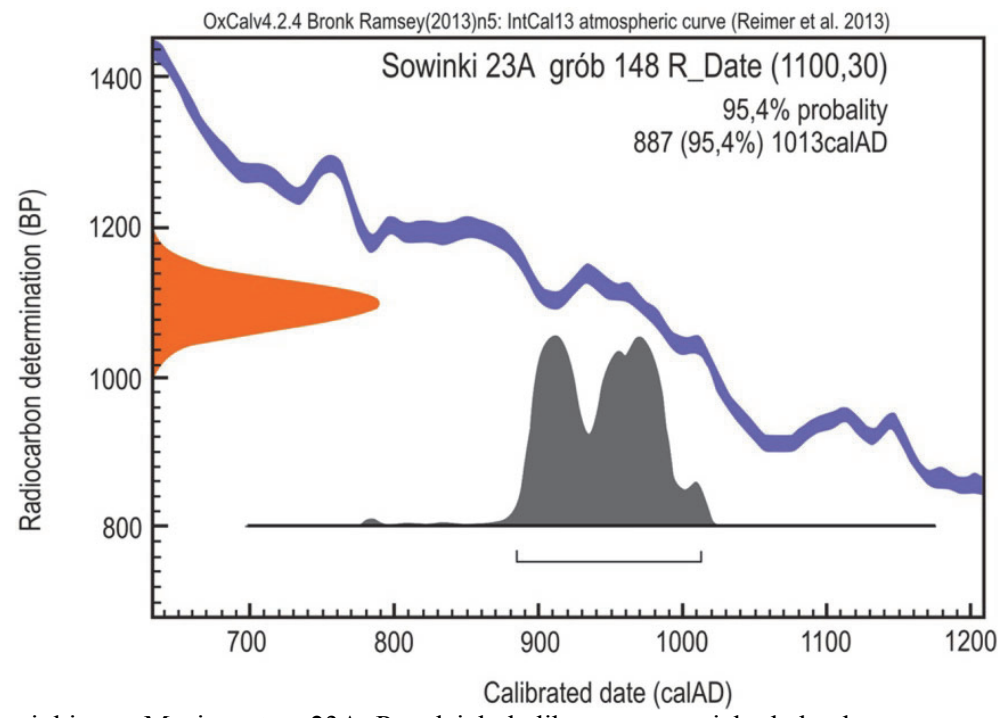

Ryc. 7. Sowinki, gm. Mosina, stan. 23A. Przedziały kalibrowanego wieku kalendarzowego na podstawie ekspertyzy ${ }^{14} \mathrm{C}$ próbki z grobu 148 wykonanej w Poznańskim Laboratorium Radiowęglowym (oprac. komp. B. Bednarczyk)

Fig.7. Sowinki, Mosina Commune, site 23A. Range of calibrated calendar age based on the ${ }^{14} \mathrm{C}$ sample from grave no. 148 dated in the Poznań Radiocarbon Laboratory (digitalised by B. Bednarczyk)

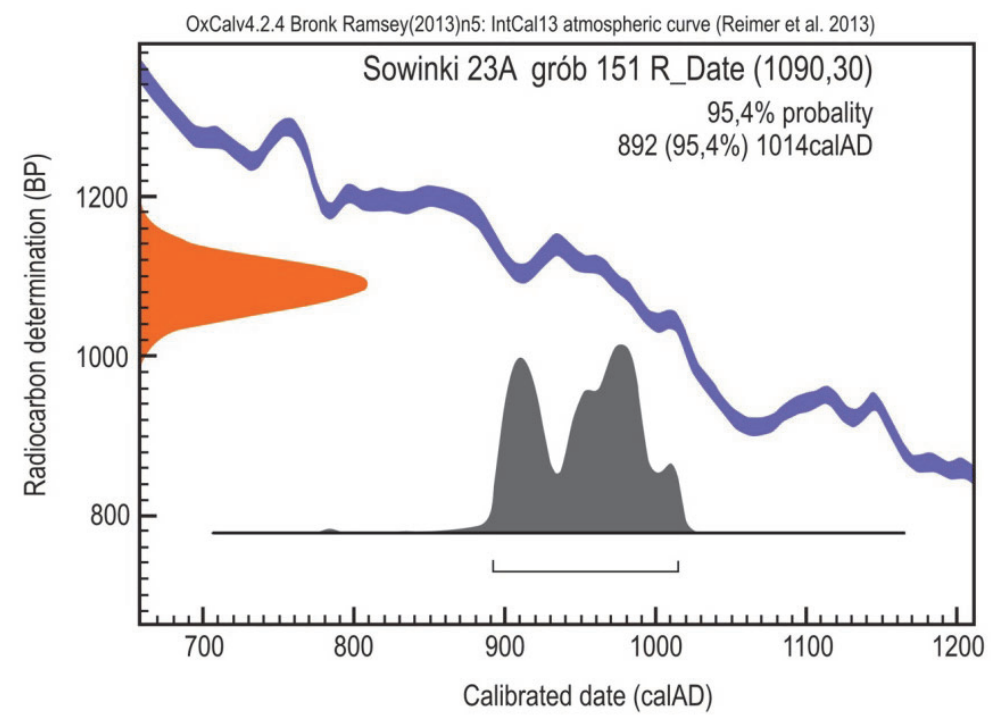

Ryc. 8. Sowinki, gm. Mosina, stan. 23A. Przedziały kalibrowanego wieku kalendarzowego na podstawie ekspertyzy ${ }^{14} \mathrm{C}$ próbki z grobu 151 wykonanej w Poznańskim Laboratorium Radiowęglowym (oprac. komp. B. Bednarczyk)

Fig. 8. Sowinki, Mosina Commune, site 23A. Range of calibrated calendar age based on the ${ }^{14} \mathrm{C}$ sample from the grave no. 151 dated in the Poznań Radiocarbon Laboratory (digitalised by B. Bednarczyk) 
Tabela 1. Zestawienie dat radiowęglowych uzyskanych dla wybranych grobów z cmentarzyska w Sowinkach, stan. 23A

Table 1. Juxtaposition of radiocarbon dates obtained for selected graves from the cemetery at Sowinki site $23 \mathrm{~A}$

\begin{tabular}{|l|c|c|c|l|c|}
\hline \multicolumn{1}{|c|}{ Próbka } & Datowanie & Kalibracja & Wiarygodność & \multicolumn{1}{|c|}{ Materiał } & Laboratorium \\
\hline Grób 61 & $1060 \pm 30 \mathrm{BP}$ & $897-1024 \mathrm{AD}$ & $94,4 \%$ & kość ludzka & Poz-43126 \\
\hline Grób 70 & $1145 \pm 30 \mathrm{BP}$ & $776-975 \mathrm{AD}$ & $95,4 \%$ & drewno & Poz-43127 \\
\hline Grób 367 & $900 \pm 30 \mathrm{BP}$ & $1039-1210 \mathrm{AD}$ & $95,4 \%$ & kość ludzka & Poz-43128 \\
\hline Grób 148 & $1100 \pm 30 \mathrm{BP}$ & $887-1013 \mathrm{AD}$ & $95,4 \%$ & kość ludzka & Poz-72015 \\
\hline Grób 151 & $1090 \pm 30 \mathrm{BP}$ & $892-1014 \mathrm{AD}$ & $95,4 \%$ & kość ludzka & Poz-64262 \\
\hline
\end{tabular}

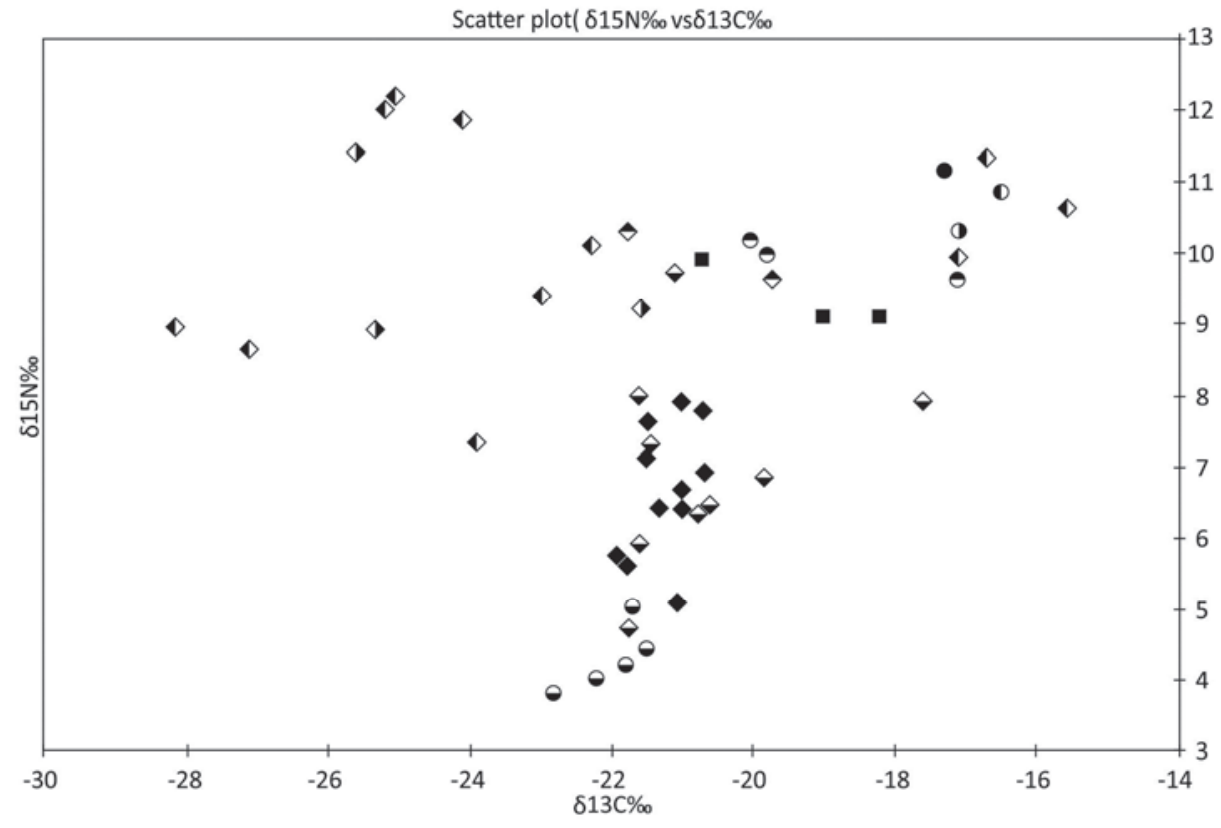

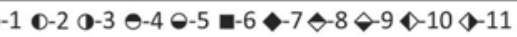

Ryc. 9. Wartości stałych izotopów azotu i węgla uzyskane z kości wybranych grobów z cmentarzyska w Sowinkach, stan. 23A oraz kości zwierzęcych ze średniowiecznych stanowisk z ziem polskich (źródło: badania własne oraz dane z Reitsema 2012). Legenda: 1 - grób komorowy nr 148, 2 - grób komorowy $\mathrm{nr}$ 151, 3 - grób elitarny $\mathrm{nr} 70,4$ - zwykłe groby $\mathrm{nr}$ 27, 94, 441, 5 - dzikie zwierzęta roślinożerne (zając, tur, łoś, jeleń), 6 - kura, 7 - udomowione zwierzęta roślinożerne (bydło, owca/koza, koń), 8 - pies, 9 - świnia, 10 - ryby, 11 - jesiotr (oprac. D. Błaszczyk)

Fig. 9. The values of carbon and nitrogen stable isotopes obtained from the bones of selected humans buried in the cemetery at Sowinki site $23 \mathrm{~A}$ and animals from various medieval sites from Poland (source: own research and data from Reitsema 2012). Legend: 1 - chamber grave no. 148, 2 - chamber grave no 151, 3 - elite grave no. 70,4 - ordinary graves no. 27, 94, 441, 5 - wild herbivores (hare, aurochs, elk, deer), 6 - hen, 7 - domesticated herbivores (cattle, sheep/goat, horse), 8 - dog, 9 - pig, 10 - fish, 11 - sturgeon (digitalised by D. Błaszczyk) 
Tabela 2. Wartości stałych izotopów azotu i węgla dla wybranych grobów z cmentarzyska w Sowinkach, stan. $23 \mathrm{~A}$

Table 2. Values of nitrogen and carbon stable isotopes obtained from the bones of selected humans buried in the cemetery at Sowinki site $23 \mathrm{~A}$

\begin{tabular}{|l|l|c|c|c|c|c|c|}
\hline \multicolumn{1}{|c|}{ Stanowisko } & \multicolumn{1}{|c|}{ Płeć i wiek } & $\delta^{13} \mathrm{~N}$ & $\delta^{13} \mathrm{C}$ & $\% \mathrm{~N}$ & $\% \mathrm{C}$ & $\mathrm{C} / \mathrm{N}$ & Badania \\
\hline Ludzie & & & & & & & \\
\hline $\begin{array}{l}\text { Sowinki, stan. 23A } \\
\text { grób 27 }\end{array}$ & $\begin{array}{l}\text { mężczyzna } \\
\text { adultus/maturus }\end{array}$ & 10,0 & $-19,8$ & 14,4 & 41,5 & 3,4 & Bradford \\
\hline $\begin{array}{l}\text { Sowinki, stan. 23A } \\
\text { grób 70 }\end{array}$ & $\begin{array}{l}\text { nieokreślona } \\
\text { juvenis }\end{array}$ & 10,3 & $-17,1$ & 16,4 & 44,9 & 3,2 & Bradford \\
\hline $\begin{array}{l}\text { Sowinki, stan. 23A } \\
\text { grób 94 }\end{array}$ & $\begin{array}{l}\text { nieokreślona } \\
\text { juvenis }\end{array}$ & 9,6 & $-17,1$ & 16,1 & 44,4 & 3,2 & Bradford \\
\hline $\begin{array}{l}\text { Sowinki, stan. 23A } \\
\text { grób 148 }\end{array}$ & $\begin{array}{l}\text { nieokreślona } \\
\text { juvenis }\end{array}$ & 11,1 & $-17,3$ & 15,3 & 42,4 & 3,2 & Bradford \\
\hline $\begin{array}{l}\text { Sowinki, stan. 23A } \\
\text { grób 151 }\end{array}$ & $\begin{array}{l}\text { nieokreślona } \\
\text { juvenis }\end{array}$ & 10,8 & $-16,5$ & 15,9 & 43,7 & 3,2 & Bradford \\
\hline $\begin{array}{l}\text { Sowinki, stan. 23A } \\
\text { grób 441 }\end{array}$ & $\begin{array}{l}\text { mężczyzna } \\
\text { dorosły }\end{array}$ & 11,1 & $-17,3$ & 15,3 & 42,4 & 3,2 & Bradford \\
\hline
\end{tabular}

Źródło: Badania wykonane w Stable Isotope Facility, University of Bradford.

Dla wybranych grobów z cmentarzyska w Sowinkach wykonano również badania stałych izotopów węgla i azotu zawartego w kolagenie z kości pochowanych

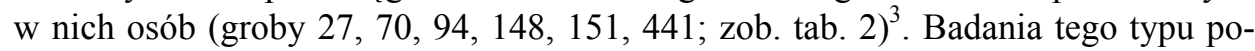
zwalają określić rodzaj diety spożywanej przez daną osobę (Brown, Brown 2011; Mays 2010, s. 265-289; Szostek, Stepańczyk 2009). Mogą one mieć również znaczenie dla interpretacji datowania radiowęglowego. Związane jest to z możliwością wystąpienia tzw. efektu rezerwuarowego (Ascough i in. 2012; Philippsen 2013, Sikora 2015). Polega on na tym, że duże spożycie organizmów wodnych w tym ryb słodkowodnych i morskich może powodować zmiany $\mathrm{w}$ akumulacji węgla ${ }^{14} \mathrm{C}$ $\mathrm{w}$ organizmie i prowadzić do postarzenia dat radiowęglowych. Uzyskane dla grobów 148 i 151 wartości izotopów węgla i azotu wskazują, że dieta pochowanych w nich osób była oparta na roślinach cyklu C3 (np. zboża - pszenica i żyto, warzywa, owoce) oraz białku zwierzęcym (mięso i mleko/ser). Wartość $\delta{ }^{13} \mathrm{C}$ sugeruje, że istotnym składnikiem diety tych osób mogły być rośliny cyklu C4 (proso). Wartości $\delta{ }^{13} \mathrm{C}$ i $\delta{ }^{15} \mathrm{~N}$ mogą wskazywać, że osoby te konsumowały też ryby dwuśrodowiskowe, takie jak np. jesiotr (tab. 2; ryc. 9).

${ }^{3}$ Badania stałych izotopów węgla i azotu zostały wykonane w Stable Isotope Facility, University of Bradford i zostały sfinansowane z grantu przyznanego p. Dariuszowi Błaszczykowi przez Narodowe Centrum Nauki w ramach finansowania stażu po uzyskaniu stopnia naukowego doktora na podstawie decyzji numer DEC-2013/08/S/HS3/00178 (projekt „Swoi czy obcy? Pochówki w grobach komorowych na ziemiach polskich w okresie wczesnego średniowiecza"). Uzyskane wyniki badań izotopowych będą przedmiotem osobnego opracowania. 
OxCalv 4.2.4 Bronk Ramsey (2013); r.5 IntCal 13 atmospheric curve (Reimer et al 2013)

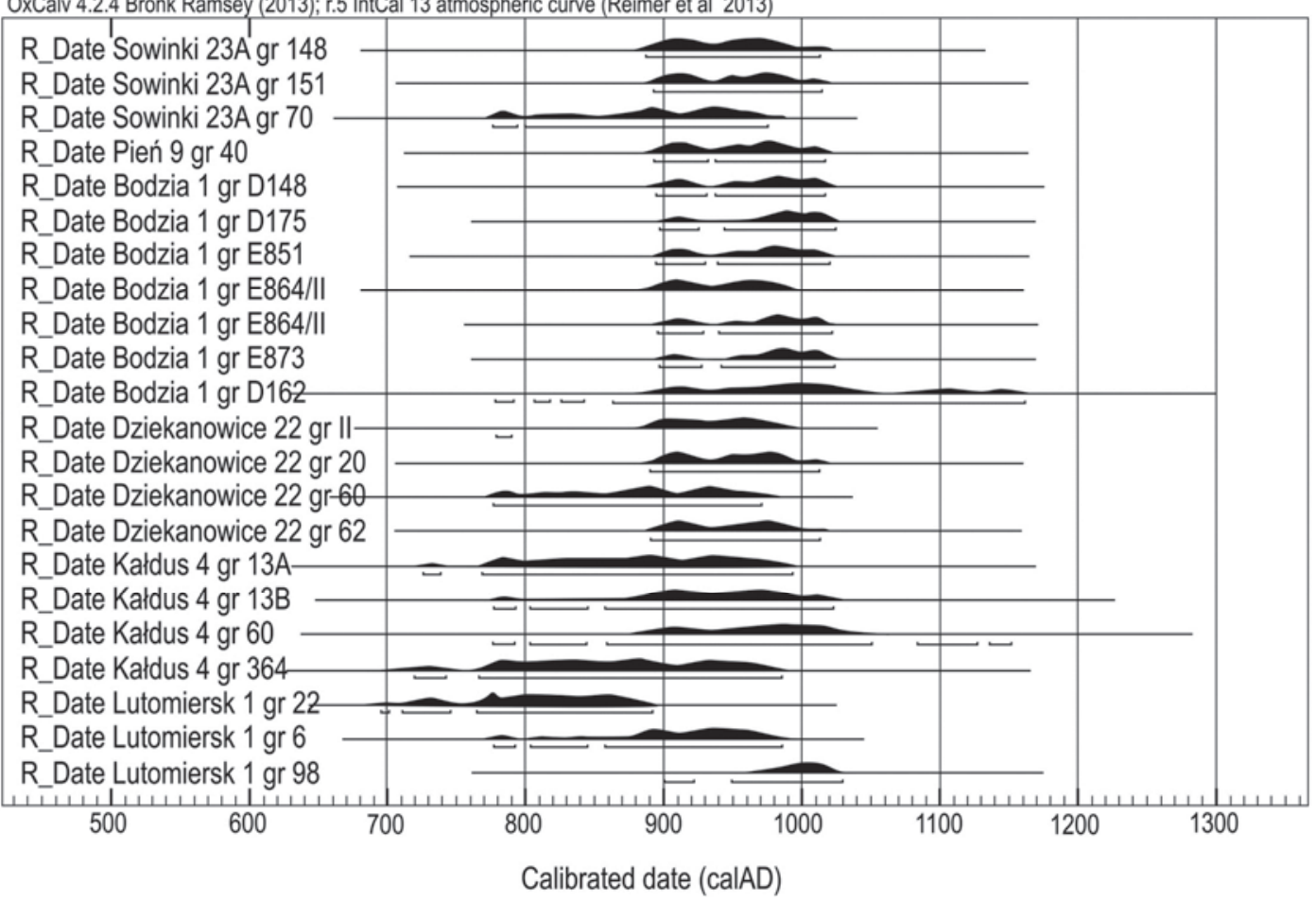

Ryc. 10. Zestawienie dat radiowęglowych uzyskanych dla wybranych grobów ze starszych faz wczesnośredniowiecznego cmentarzyska z obszaru ziem polskich (Sowinki, stan. 23A, Pień, stan. 9, Bodzia, stan. 1, Dziekanowice, stan. 22, Kałdus, stan. 4, Lutomiersk, stan. 1), (oprac. D. Błaszczyk)

Fig. 10. Comparison of radiocarbon dates obtained for selected graves form older phases of early medieval cemetery in the Polish lands (Sowinki site 23A, Pien site 9, Bodzia site 1, Dziekanowice site 22, Kałdus site 4, Lutomiersk site 1), (digitalised by D. Błaszczyk)

Wydaje się że daty radiowęglowe uzyskane dla grobów 148 i 151 nie wykazują istotnego wpływu efektu rezerwuarowego. Otrzymane daty mieszczą się w oczekiwanym horyzoncie czasowym, potwierdzonym przez kontekst archeologiczny znalezisk i datowanie typologiczne przedmiotów wchodzących w skład wyposażenia grobowego. Ponadto groby komorowe nr 148 i 151 wpisują się w horyzont innych grobów, w tym grobów komorowych, z ziem polskich, które można datować na 2. połowę X i 1. połowę XI w. Takie groby odkryto m.in. na cmentarzysku w Bodzi, stan. 1 (Buko 2015 red.), Dziekanowicach, stan. 22 (Wrzesińska, Wrzesiński 2016), Kałdusie, stan. 4 (Chudziak red. 2010, 2013; Bojarski i in. 2016), Pniu, stan. 9 (Drozd, Janowski, Poliński 2009; Sikora 2015) i Lutomiersku, stan. 1 (Grygiel 2014). Pochodzą one $z$ najstarszych faz funkcjonowania wspomnianych cmentarzysk odpowiadającej czasom pierwszej monarchii piastowskiej (ryc. 10). 


\section{PODSUMOWANIE}

Groby nr 148 i 151 z cmentarzyska w Sowinkach stanowią przykład nielicznych na ziemiach polskich wczesnośredniowiecznych grobów komorowych. W obu grobach najprawdopodobniej pochowano młodych mężczyzn, którym towarzyszyło bogate wyposażenie grobowe.

Wynik datowania bezwzględnego metodą węgla radioaktywnego pozwala datować oba groby na X w., a uszczegółowiając najprawdopodobniej na drugą jego połowę lub sam początek XI w. Można założyć, że zarówno grób nr 148, jak i 151 należą do jednych z najstarszych, być może nawet założycielskich pochówków na cmentarzysku w Sowinkach. Chociaż znajdują się na południowym skraju przebadanego cmentarzyska, to biorąc pod uwagę, że jest to jego najstarsza część, która rozwijała się w kierunku północnym, pierwotnie wspomniane groby mogły się znajdować w jego centrum. Biorąc pod uwagę daty radiowęglowe, można przyjąć, że jako pierwszy powstał grób nr 148, a jako następny, nieco później, grób nr 151 (ryc. 9). Oba groby powstały w czasach tzw. pierwszej monarchii piastowskiej, najprawdopodobniej za czasów panowania Bolesława Chrobrego lub nawet Mieszka I, czyli w okresie intensywnej chrystianizacji, tworzenia się dużego zróżnicowania społecznego i rozwoju struktur wczesnopaństwowych na ziemiach polskich. Uzyskane daty przy pomocy metod przyrodniczych potwierdziły wcześniejsze ustalenia w tym zakresie oparte na tradycyjnej analizie materiałów archeologicznych (Krzyszowski 1992, 1995, 1997, 2014).

\section{BIBLIOGRAFIA}

Aner E.

1952 Die wikingerzeitlichen Kammergräber am Thorsberger Moor. Offa, 11, s. 60-78.

Ascough P.L., Church M.J., Cook G.T., Dunbar E., Gestsdóttir H., McGovern T.H., Dugmore A., Friðriksson J., Edwards K. J.

2012 Radiocarbon reservoir effects in human bone collagen from northern Iceland. Journal of Archaeological Science, 39(7), s. 2261-2271, DOI: 10.1016/j.jas.2012.02.012.

Błaszczyk D., Stępniewska D. (red.)

$2016 \quad$ Pochówki $w$ grobach komorowych na ziemiach polskich w okresie wczesnego średniowiecza. Warszawa: Instytut Archeologii Uniwersytet Warszawskiego.

Bojarski J., Chudziak W., Kozłowski T., Reitsema L.

2016 Wczesnośredniowieczne groby komorowe z ziemi chełmińskiej. W: D. Błaszczyk, D. Stępniewska (red.), Pochówki $w$ grobach komorowych na ziemiach polskich $w$ okresie wczesnego średniowiecza (s. 102-121). Warszawa: Instytut Archeologii Uniwersytetu Warszawskiego.

Brown T., Brown K.

2011 Biomolecular Archaeology. An Introduction. Chichester: Wiley-Blackwell.

Buko A. (red.)

2015 Bodzia. A Late Viking-Age Elite Cemetery in Central Poland. Leiden - Boston: Brill. 
Chudziak W. (red.)

2010 Wczesnośredniowieczne cmentarzysko szkieletowe w Katdusie (stanowisko 4), (Mons Sancti Laurentii 5). Torun: Wydawnictwo Naukowe Uniwersytet Mikołaja Kopernika.

Chudziak W.

2013 Remarks on particular material traces of Scandinavian culture in Pomerania. W: S. Moździoch, B. Stanisławski, P. Wiszewski (red.), Scandinavian Culture in Medieval Poland (Interdisciplinary Medieval Studies 2), (s. 373-393). Wrocław: Institute of Archaeology and Ethnology PAN.

Drozd A., Janowski A., Poliński D.

2009 Wczesnośredniowieczne groby komorowe na cmentarzysku w Pniu koło Bydgoszczy (Badania 2005-2007). W: A. Janowski, K. Kowalski, S. Słowiński (red.), XVI sesja Pomorzoznawcza, część 1. Od epoki kamienia do okresu wczesnośredniowiecznego (Acta Archaeologica Pomoranica III) (s. 351-366). Szczecin: SNAP o. Szczecin.

Gąssowski J.

1952 (1950) Cmentarzysko w Końskich na tle zagadnienia południowej granicy Mazowsza we wczesnym średniowieczu. Materiały Wczesnośredniowieczne, 2, s. 71-175.

Goslar T.

2014 Raport $z$ wykonania datowań C-14 w Poznańskim Laboratorium Radiowęglowym, Sowinki, stan. 23A, grób 151. Poznań (maszynopis w posiadaniu autorów).

Goslar T.

2015 Raport $z$ wykonania datowań C-14 w Poznańskim Laboratorium Radiowęlowym, Sowinki, stan. 23A, grób 148. Poznań (maszynopis w posiadaniu autorów).

Grygiel R.

2014 Aneks nr 2: Cmentarzysko wareskich drużynników w Lutomiersku. W: R. Grygiel, T. Jurek (red.), Początki Łęczycy, t. 2, Archeologia o początkach Łęczycy (s. 679-751). Łódź: Muzeum Archeologiczne i Etnograficzne w Łodzi.

Hilczerówna Z.

1956 Ostrogi polskie z X-XIII wieku. Poznań: Państwowe Wydawnictwo Naukowe.

Janowski A.

2011a Early medieval chamber graves on the south coast of the Baltic Sea. W: F. Biermann,

T. Kersting, A. Klammt (red.), Der Wandel um 1000. Beiträge der Sektion zur slawischen Frühgeschichte der 18. Jahrestagung des Mittel- und Ostdeutschen Verbandes für Altertumsforschung in Greifswald, 23. bis 27. März 2009 (Beiträge zur Ur- und Frühgeschichte Mitteleuropas, t. 60, s. 57-267). Langenweissbach: Beier \& Beran. Archäologische Fachliteratur.

2011b „Jeśli umrze ktoś znaczny z nich, kopią dlań grób podobny do obszernego domu...”. Kilka uwag o tzw. grobach komorowych na terenie Europy Środkowej i Wschodniej. W: S. Cygan, M. Glinianowicz, P.N. Kotowicz (red.), In Silvis, Campis... et Urbe. Średniowieczny obrządek pogrzebowy na pograniczu polsko-ruskim (s. 385-402). Rzeszów - Sanok: Mitel.

Ježek M., Krzyszowski A., Zavřel J.

2013 Early medieval touchstones from Sowinki, Greater Poland. Germania, 91(1-2), s. 177-186.

Kara M.

1991 Z badań nad wczesnośredniowiecznymi grobami z uzbrojeniem z terenu Wielkopolski. W: L. Leciejewicz (red.), Od plemienia do państwa. Ślask na tle wczesnośredniowiecznej Stowiańszczyzny zachodniej (s. 99-120). Wrocław - Warszawa: Volumen.

Kempke T.

1991 Starigard/Oldenburg. Hauptburg der Slawen in Wagrien. 3 DieWaffen des 8.-13. Jahrhunderts (Offa-Bücher 73). Neumünster: Wachholtz Verlag. 
Kozak J.

1996 Wczesnośredniowieczne cmentarzysko szkieletowe w Sowinkach (gm. Mosina, woj. poznańskie): analiza antropologiczna i paleodemograficzna. Przegląd Antropologiczny, 59, s. 91-96.

Kmietowicz A.

1994 Dirhem arabski z Sowinek. Kraków (maszynopis w posiadaniu autorów).

Krzyszowski A.

1992 Wstępne wyniki badań archeologicznych na wczesnośredniowiecznym cmentarzysku szkieletowym z X/XI-XI wieku w miejscowości Sowinki, gm. Mosina, woj. poznańskie, stanowisko 23A. Wielkopolskie Sprawozdania Archeologiczne, 1, s. 83-102.

Krzyszowski A.

1995 Ein reiches Gräberfeld aus dem 10./11.Jh. in Sowinki bei Poznań in Grosspolen. Slavia Antiqua, 36, s. 49-72.

Krzyszowski A.

1997 Frümittelalterliches Grab eines Kaufmannes aus Sowinki bei Poznań in Grosspolen. Germania, 75(2), s. 639-671.

Krzyszowski A.

2014 Naczynia ceramiczne i wiaderka klepkowe z wczesnośredniowiecznego cmentarzyska w Sowinkach k. Poznania. W: T. Kurasiński, K. Skóra (red.), Grób w przestrzeni, przestrzeń w grobie (Acta Archaeologica Lodziensia 60) (s. 137-158). Łódź: Wydawnictwo

Kurasiński T., Skóra K.

Łódzkiego Towarzystwa Naukowego.

2012a Wczesnośredniowieczne cmentarzysko szkieletowe w Lubieniu, pow. piotrkowski. Łódź: Instytut Archeologii i Etnologii PAN.

Kurasiński T., Skóra K.

2012b Militaria z wczesnośredniowiecznego cmentarzyska szkieletowego w Radomiu, stan. 4. Acta Militaria Mediaevalia, 8, s. 69-89.

Leciejewicz L.

1954 Cmentarzysko w Birce. Archeologia, 6, s.141-159.

Leciejewicz L., Łosiński W.

1960 Wczesnośredniowieczne cmentarzysko w Młodzikowie w pow. średzkim. Fontes Archaeologici Posnanienses, 11, s. 104-165.

Mays S.

2010 The Archaeology of Human Bones. London and New York: Routledge.

Morawski W., Zaitz E.

1977 Wczesnośredniowieczne cmentarzysko szkieletowe w Krakowie na Zakrzówku. Materiaty Archeologiczne, 17, s. 53-169.

Müller-Wille M.

2015 The cemetery at Bodzia in a broader European context. W: A. Buko (red.), Bodzia. A Late Viking-Age Elite Cemetery in Central Poland (s. 479-510), Leiden - Boston: Brill.

Nadolski A.

1954 Studia nad uzbrojeniem polskim w X, XI I XII wieku. Łódź: Zakład Narodowy im. Ossolińskich.

Nadolski A., Abramowicz A., Poklewski T.

1959 Cmentarzysko z XI wieku w Lutomiersku pod Łodzią (Acta Archaeologica Universitatis Lodziensis 7). Łódź: Łódzkie Towarzystwo Naukowe, Zakład Narodowy im. Ossolińskich. 
Petersen J.

1919 De norske vikingesverd. En typologisk-kronologisk studie over vikingetidens vaaben. Kristiania: I kommission hos Jacob Dybwad.

Philippsen B.

2013 The freshwater reservoir effect in radiocarbon dating. Heritage Science 1(24). DOI:10.1186/2050-7445-1-24.

Ratajczyk Z.

2013 The cemetery in Ciepłe - current research results. W: S. Moździoch, B. Stanisławski, P. Wiszewski (red.), Scandinavian culture in miedieval Poland (s. 323-351). Wrocław: Institute of Archaeology and Ethnology of the Polish Academy of Sciences.

Rajewski Z. A.

1938 Wielkopolskie cmentarzyska rzędowe okresu wczesnodziejowego. Przegląd Archeologiczny, 6(1), s. 28-85.

Reitsema, L.J.

2012 Stable Isotope Evidence for Human Diet Change in Poland. Columbus: Department of Anthropology, The Ohio State University (niepublikowana praca doktorska).

Sawicki T.

2008 Wczesnośredniowieczne cmentarzysko szkieletowe w Daniszewie pod Kołem, woj. wielkopolskie. Slavia Antiqua, 49, s. 149-209.

Sikora J.

2013 O interpretacji etnicznej wczesnośredniowiecznych pochówków elitarnych. Skandynawowie w państwie pierwszych Piastów i na Pomorzu? Slavia Antiqua, 44, s. 61-96.

Sikora J.

2015 Początki inhumacji w Polsce pierwszych Piastów. Jak wczesne? W: W. Dzieduszycki, J. Wrzesiński (red.), Funeralia Lednickie, Spotkanie 17. Cmentarzyska - relacje spoteczne i międzykulturowe (s. 151-164). Poznań: SNAP o. Poznań.

Szostek K., Stepańczyk B.

2009 Zastosowanie analizy stabilnych izotopów w antropologii - wstępne wyniki badań. W: W. Dzieduszycki, J. Wrzesiński (red.), Funeralia Ldnickie, Spotkanie 11. Metody. Źródta. Dokumentacja (s. 125-140). Poznań: SNAP o. Poznań.

Tokarski W.

2000 Militaria - broń miotająca, obuchowa i drzewcowa oraz elementy rzędu końskiego i oporządzenia jeździeckiego. W: Z. Kurnatowska (red.), Wczesnośredniowieczne mosty przy Ostrowie Lednickim, t. 1, Mosty traktu gnieźnieńskiego (s. 77-103). Lednica - Toruń: Muzeum Pierwszych Piastów na Lednicy, Instytut Archeologii i Etnologii UMK.

Unwerzagt W., Schuldt E.

1963 Teterow. Ein slawischer Burgwall in Mecklenburg. Berlin: Akademie Verlag Berlin.

Wachowski K.

1984 Militaria z grodu na Ostrówku w Opolu. W: B. Gediga (red.), Studia nad kultura wczesnopolskiego Opola. Militaria - wyroby bursztynowe (s. 11-112). Wrocław - Warszawa - Kraków - Gdańsk: Zakład Narodowy im. Ossolińskich.

Wachowski K.

1988 Merowingische und karolingische Sporen auf dem Kontinent. Zeitschrift für Archäologie des Mittelalters, 14/15, s. 49-79.

Wachowski K.

1992 Kultura karolińska a Słowiańszczyzna zachodnia. Studia Archeologiczne, 23. Wrocław: Wydawnictwo Uniwersytetu Wrocławskiego. 
Walanus A., Goslar T.

2009 Datowanie radiowęglowe. Kraków: Wydawnictwo AGH.

Wrzesiński J.

2010 Kto wierzy w Odyna? Czyli zagadkowe groby w państwie Piastów. W: M. Bogacki, M. Franz, Z. Pilarczyk (red.), Religia ludów Morza Battyckiego. Stosunki polsko-duńskie w dziejach, Mare Integrans. Studia nad dziejami wybrzeży Morza Battyckiego (s. 58-76). Toruń: Wydawnictwo Adam Marszałek.

Wrzesińska A, Wrzesiński J.

2016 Groby komorowe z Dziekanowic, gm. Łubowo, woj. wielkopolskie. W: D. Błaszczyk, D. Stępniewska (red.), Pochówki w grobach komorowych na ziemiach polskich w okresie wczesnego średniowiecza (s. 80-89). Warszawa: Instytut Archeologii Uniwersytetu Warszawskiego.

Żak J.

1967 „Importy” skandynawskie na ziemiach zachodniostowiańskich od IX do XI wieku (część analityczna). Poznań: Państwowe Wydawnictwo Naukowe.

Żak J.

1968 Materiały do studiów nad kontaktami wschodniopomorsko-skandynawskimi z X i XI wieku - broń skandynawska. Pomorania Antiqua 2, s. 287-314.

\section{RADIOCARBON DATING OF CHAMBER GRAVES FROM THE EARLY MEDIEVAL CEMETERY AT SOWINKI (SITE 23A) IN WIELKOPOLSKA}

\section{Summary}

Sowinki, site 23A, is located about $35 \mathrm{~km}$ southeast of Poznań (fig. 1). From 1989 to 1991, the site was subject to rescue excavations conducted by Andrzej Krzyszowski from the former Polish Studios for the Conservation of Cultural Property in Poznan. The excavations produced the remains of Mesolithic, Neolithic, Lusatian, Pomeranian and Przeworsk cultures and medieval occupations, along with an early medieval inhumation cemetery (Krzyszowski 1992, 1995, 1997, 2014). The cemetery consisted of 150 graves with 158 burials of women, men and children. These were typical early medieval Christian pit graves. Most of them had rectangular-shaped burial pits oriented east-west, with only a few oriented along the north-south axis. Funerary equipment was found in 82 burials. The burial ground at Sowinki was used from the second half of the $10^{\text {th }}$ century to the mid- $12^{\text {th }}$ century. Based on the form of the graves, funerary equipment and some radiocarbon dates (grave $701145 \pm 30 \mathrm{BP}$; grave 61 1060 \pm 30 ; BP; grave $367900 \pm 30 \mathrm{BP}$ ), two chronological phases of the use of the cemetery were discerned: 1) the older phase with randomly arranged graves and large burial pits - from the second half of the $10^{\text {th }}$ century to the first half of the $11^{\text {th }}$ century, 2) the younger phase with graves arranged in rows and narrow burial pits - from the first half of the $11^{\text {th }}$ century to the first half of the $12^{\text {th }}$ century.

Several uncovered graves differed from other graves in the cemetery in form and type of grave goods. With a high probability, two of them (graves no. 148 and 151) can be regarded as the so-called chamber graves. They were characterised by large burial pits, traces of wooden structures and rich grave goods. Both of them were situated at the edge of the cemetery, in line, one behind 
the other (fig. 2). They were one of the very first early medieval chamber graves discovered on the Polish lands. Similar features were then recognized and excavated e.g. at Kałdus, site 4, Pień, site 9, Bodzia, site 1, Dziekanowice, site 22, Ciepłe, site 6 and some others (see Błaszczyk, Stępniewska eds 2016; Janowski 2011a, 2011b, 2015; Müller-Wille 2015; Sikora 2013; Wrzesiński 2010).

Judging by funerary equipment, grave no. 148 (fig. 3:1, 4, 5) contained probably the remains of a man, who died as juvenis. The pit of grave 148 had a rectangular shape with rounded corners. It measured 3.78 in length, 2.60 in width and 1.19 in depth. The deceased was buried in a coffin with iron fittings (four pairs). He was placed in supine position on his back with arms stretched along the body, straight legs and face facing west. The man was accompanied by two iron knives in one leather sheath with fittings covered with a golden badge and decorated with a stylised image of an adder or a dragon, a touchstone, a wooden bucket, a silver ring, $1 / 4$ of an Arabic silver dirham (coined between 950 and 976).

A man at the age of juvenis was also probably buried in grave no. 151 (fig. 3:2, 6). The grave pit, oriented along the east-west axis, had a rectangular shape with rounded corners. It was 3.64 long, 2.30 wide and $1.08-1.11$ deep. The deceased was placed on his back in a wooden coffin with arms stretched along the body, straight legs and face turned to the west. Deposited by the deceased were two iron knives in a common leather sheath with bronze fittings decorated with a stylised image of an adder or a dragon, an iron spearhead (type G according to J. Petersen 1919 or type III according to A. Nadolski 1954), two iron spurs (type I: 1-2 according to Z. Hilczerówna 1956), an iron clasp for a spur, a wooden bucket covered with a silvered iron sheet, an iron object, which could probably serve as an awl, and another iron object, perhaps a razor.

To determine the absolute age of both chamber graves, samples were taken from the preserved fragments of deposited bones. The ${ }^{14} \mathrm{C}$ dating was conducted in the Poznan Radiocarbon Laboratory with the use of AMS technique. The calibration of the obtained radiocarbon dates was performed using the software OxCal v 4.2, with reference to the curve Intcal1 13 (Goslar, Walanus 2004). Grave no. 148 produced a date $1100 \pm 30 \mathrm{BP}$ (Poz-72015), which after calibration falls in the range $887-1013 \mathrm{AD}$ (with the probability of $95.4 \%$; fig. 7). Grave no. 151 yielded the date $1090 \pm 30$ BP (Poz-64262). Calibrated, it can be placed in the range $892-1014$ AD (with the probability of $95.4 \%$; fig. 8 ).

Stable isotopes of carbon and nitrogen from bone collagen were also analysed for selected graves from a cemetery at Sowinki (see table 1, fig. 9). Values of carbon and nitrogen isotopes obtained for the graves no. 148 and 151 showed that the diet of people buried in them was based on C3 plants (e.g. wheat, rye, vegetables, fruit) and animal products (meat of terrestrial mammals, e.g. cow, pig, sheep, milk, cheese, eggs). The value of $\delta^{13} \mathrm{C}$ indicated that an important component of their diet could be also $\mathrm{C} 4$ plants (millet) and the values of $\delta^{13} \mathrm{C}$ and $\delta^{15} \mathrm{~N}$ suggest that they could also consume anadromous fish (e.g. sturgeon). The information regarding the diet can be significant for the interpretation of radiocarbon dating, due to the so-called reservoir effect. It results from considerable consumption of freshwater and marine fish, which can affect the accumulation of ${ }^{14} \mathrm{C}$ in organisms, thereby producing earlier radiocarbon dates. Nevertheless, radiocarbon dates obtained for graves 148 and 151 seem to be largely unaffected by the reservoir effect and their ${ }^{14} \mathrm{C}$ age falls within the expected range.

The results of radiocarbon dating confirmed the previous dating based on archaeological materials. Both graves can be dated to the second half of the $10^{\text {th }}$ century or the very beginning of the $11^{\text {th }}$ century. However, grave 148 was probably dug out as first; grave 151 was later. It can be 
assumed that chamber graves from Sowinki, site 23A, belong to the earliest founding graves in the cemetery, constructed during the reign of Bolesław I the Brave or maybe even Mieszko I. This time saw the formation of state structures, the development of social differentiation and Christianisation. The chamber graves from Sowinki are part of the archaeological horizon of inhumation graves in the Polish lands, which can be dated to the second half of the $10^{\text {th }}$ century and the first half of the $11^{\text {th }}$ century, e.g. Bodzia, site 1 (Buko 2015 ed.); Dziekanowice, site 22 (Wrzesińska, Wrzesiński 2016); Kałdus, site 4 (Chudziak ed. 2010, 2013; Bojarski et al. 2016); Pień, site 9 (Drozd, Janowski, Poliński 2009; Sikora 2015), and Lutomiersk, site 1 (Grygiel 2014), (fig. 10). 